The Canadian Mineralogist

Vol. 38, pp. 861-868 (2000)

\title{
TETRAHEDRALLY COORDINATED BORON IN A TOURMALINE: BORON-RICH OLENITE FROM STOFFHÜTTE, KORALPE, AUSTRIA
}

\author{
JOHN M. HUGHES ${ }^{\S}$ \\ Department of Geology, Miami University, Oxford, Ohio 45056, U.S.A.
}

ANDREAS ERTL

Institut für Mineralogie und Kristallographie, Geozentrum, Universität Wien, Althanstraße 14, A-1090 Wien, Austria

M. DARBY DYAR

Department of Geography and Geology, Mount Holyoke College, South Hadley, Massachusetts 01075, U.S.A.

\author{
EDWARD S. GREW
}

Department of Geological Sciences, University of Maine, Orono, Maine 04469-5711, U.S.A.

\section{CHARLES K. SHEARER}

Institute of Meteoritics, University of New Mexico, Albuquerque, New Mexico 87131, U.S.A.

MARTIN G. YATES AND CHARLES V. GUIDOTTI

Department of Geological Sciences, University of Maine, Orono, Maine 04469-5711, U.S.A.

\begin{abstract}
The substitution of ${ }^{[4]} \mathrm{B}$ for ${ }^{[4]} \mathrm{Si}$ in tourmaline has been the source of much discussion. A sample of olenite from Stoffhütte, Koralpe, Styria, Austria has been found to contain more than one ${ }^{[4]} \mathrm{B}$ per formula unit of $31(\mathrm{O}, \mathrm{OH}, \mathrm{F})$, demonstrating that significant ${ }^{[4]} \mathrm{B}={ }^{[4]} \mathrm{Si}$ substitution does indeed occur in tourmaline. The composition of the structurally characterized crystal was determined using electron microprobe and SIMS data; in combination with refinement of the site scattering, the chemical data yield an optimized formula of ${ }^{Y}\left(\mathrm{Na}_{0.400} \mathrm{Ca}_{0.294} \square_{0.306}\right){ }^{Z}\left(\mathrm{Al}_{2.424} \mathrm{Li}_{0.357} \square_{0.219}\right)\left(\mathrm{Al}_{5.916} \square_{0.084}\right) \mathrm{B}_{3.00}\left(\mathrm{Si}_{4.854} \mathrm{~B}_{1.062} \mathrm{Al}_{0.084}\right)_{\Sigma 6.00} \mathrm{O}_{27}$ $\left[\mathrm{F}_{0.06}(\mathrm{OH})_{3.31} \mathrm{O}_{0.63}\right]$. The Austrian olenite crystallizes in space group R3m, $a$ 15.731(3), c 7.0638(9) $\AA$. The atomic arrangement was refined to $R=0.014$ using X-ray data; $\langle T-\mathrm{O}\rangle$ is equal to $1.609 \AA$, reflecting substitution of the smaller boron atom for $\mathrm{Si}$. Conjecture on the pattern of distribution of ${ }^{[4]} \mathrm{B}$ can be made on the basis of $X$-site occupancy.
\end{abstract}

Keywords: tourmaline, olenite, boron, crystal structure.

\section{SOMMAIRE}

La possibilité d'une substitution de ${ }^{[4]} \mathrm{B}$ pour ${ }^{[4]} \mathrm{Si}$ dans la tourmaline a fait couler beaucoup d'encre. Un échantillon d'olénite provenant de Stoffhütte, Koralpe, Styrie, en Autriche, possède plus d'un atome de ${ }^{[4]} \mathrm{B}$ par unité formulaire de $31(\mathrm{O}, \mathrm{OH}, \mathrm{F})$, démontrant ainsi l'importance de la substitution ${ }^{[4]} \mathrm{B}={ }^{[4]} \mathrm{Si}$ dans la tourmaline. La composition du cristal choisi pour caractérisation structurale a été établie en utilisant la microsonde électronique et la microsonde ionique. Ces données, avec les résultats d'un affinement de la dispersion associée aux sites, mènent à une formule optimisée, ${ }^{Y}\left(\mathrm{Na}_{0.400} \mathrm{Ca}_{0.294} \square_{0.306}\right)^{Z}\left(\mathrm{Al}_{2.424} \mathrm{Li}_{0.357} \square_{0.219}\right)$ $\left(\mathrm{Al}_{5.916} \square_{0.084}\right) \mathrm{B}_{3.00}\left(\mathrm{Si}_{4.854} \mathrm{~B}_{1.062} \mathrm{Al}_{0.084}\right)_{\Sigma 6.00} \mathrm{O}_{27}\left[\mathrm{~F}_{0.06}(\mathrm{OH})_{3.31} \mathrm{O}_{0.63}\right]$. L'olénite autrichienne cristallise selon le groupe spatial $R 3 m, a 15.731(3), c$ 7.0638(9) A. L'agencement des atomes a été affiné jusqu'à un résidu $R$ égal à 0.014 en utilisant les données prélevées par diffraction X. La longueur moyenne $\langle T-\mathrm{O}>$ est égale à $1.609 \AA$ A , ce qui témoigne d'une substitution du bore, plus petit, pour le Si. Nous évaluons les schémas de distribution de ${ }^{[4]} \mathrm{B}$ à la lumière des taux d'occupation du site $X$.

Mots-clés: tourmaline, olénite, bore, structure cristalline.

§-mail address: hughesjm@muohio.edu 


\section{INTRODUCTION}

Tourmaline is one of the more complex silicate minerals, and it has resisted detailed understanding longer than most common silicates. One of the more controversial substitutions in tourmaline is $\mathrm{B} \Leftrightarrow \mathrm{Si}$ at the tetrahedrally coordinated $(T)$ site. It is difficult to analyze samples for boron by electron microprobe, and difficult to detect small amounts of substituent B in X-ray structure studies. Although the presence of tetrahedrally coordinated B has been demonstrated in tourmaline using magic-angle-spinning nuclear magnetic resonance (MAS NMR) (Tagg et al. 1999) and substantial ${ }^{[4]} \mathrm{B}$ substitution for $\mathrm{Si}$ has been reported in synthetic olenite (Wodara \& Schreyer 1997, 1998, Schreyer et al. 2000), no structural study has unequivocally shown B to occur in amounts greater than 3 apfu (atoms per formula unit) in tourmaline (e.g., Burns et al. 1994, Hawthorne 1996, Bloodaxe et al. 1999), with a single exception. Ertl et al. (1997) reported the presence in a sample of olenite of significant excess B by electron-microprobe analysis. Their subsequent study of the structure, done on an unanalyzed crystal, indicated a significant level of B at the $T$ site, although there was a large disparity (nearly a factor of 2) between the amount established by chemical analysis and that inferred from the structure analysis. Because previous investigators have not quantitatively demonstrated that B substitutes for Si to any significant degree at the tetrahedral site in natural tourmaline, we undertook a single-crystal structure study of AE's olenite and analyzed the same crystal by electron and ion microprobe.

\section{OCCURRENCE}

The Koralpe and Saualpe crystalline series in southeastern Austria represent the easternmost parts of the greater Austroalpine thrust mass of the Eastern Alps. These polymetamorphic series are composed mainly of mica schists and paragneisses, with intercalation of eclogites, amphibolites, marbles and deformed Permian granitic pegmatites $(\mathrm{Sm}-\mathrm{Nd}$ garnet whole-rock ages from pegmatites are ca. $260 \mathrm{Ma}$; Thöni \& Miller 1996). The olenite-bearing metapegmatite, from Stoffhütte, Koralpe, Styria, Austria, is discordant with respect to the boundary between mylonitic gneiss - quartzite and gneiss - mica schist (Ertl \& Brandstätter 1998). Because there is no clear evidence for the existence of granitic pegmatites in the Koralpe that are not of Permian age, this olenite-bearing pegmatite is assumed also to be of Permian age. Petrological and geochronological data show that large parts of the Koralpe and the Saualpe have experienced intense deformation and metamorphism during the eo-Alpine orogeny. Peak conditions reached up to $2 \mathrm{GPa}$ between 650 and $700^{\circ} \mathrm{C}, 100 \pm 10$ Ma ago (Stüwe \& Powell 1995, Thöni \& Miller 1996, Miller \& Thöni 1997, Lichem et al. 1997, Thöni 1999).
The minerals associated with the B-rich olenite are albite, muscovite, quartz, schorl, zircon, fersmite, microlite, opal, pyromorphite, apatite, beryl, uraninite and uranophane (Postl \& Moser 1988, Ertl \& Brandstätter 1998). Electron-microprobe analysis of the muscovite ( $2 M_{1}$ polytype) gave $2.86 \mathrm{wt} \% \mathrm{~B}_{2} \mathrm{O}_{3}(0.32 \mathrm{~B}$ per $12 \mathrm{O}$ ), and crystal-structure refinement gave average $\langle T-\mathrm{O}\rangle$ bond lengths of $1.632 \AA$ for both tetrahedrally coordinated sites. Boron was inferred to substitute for ${ }^{[4]}(\mathrm{Si}, \mathrm{Al})$ (Bernhardt et al. 1999). Schorl (Ertl \& Hughes, in prep.) is present as distinct crystals or intergrown with the olenite. The paragenetic relations of the various species of tourmaline in the pegmatite are being studied by the second author and his colleagues at the University of Vienna and by Werner Schreyer and his colleagues at the Ruhr-Universität Bochum, Germany.

\section{EXPERIMENTAL}

\section{Crystal structure}

A single crystal of the olenite from Koralpe, Styria, Austria, characterized by Ertl et al. (1997), was isolated and ground to a sphere $170 \mu \mathrm{m}$ in diameter. The crystal was mounted on an Enraf-Nonius CAD4 single-crystal diffractometer, and the unit cell (Table 1) was determined from least-squares refinement of the setting angles of 25 reflections, each measured in four positions.

Intensity data were collected using the parameters in Table 1, and reduced to structure factors using the SDP FOR WINDOws package of programs (Frenz 1997). We collected more than a hemisphere of reciprocal space, and selected our approximate hemisphere equivalent to that in the original Ertl et al. (1997) study. That hemisphere is a "non-conventional" one in studies of tourmaline structure $( \pm h, \pm k,+l)$, one that emphasizes redundant data over unique data; however, collection of data to $70^{\circ} 2 \theta$ provided sufficient data for a high-preci-

TABLE 1. CRYSTAL DATA AND RESULTS OF STRUCTURE REFINEMENT FOR AUSTRIAN OLENITE

\begin{tabular}{|c|c|c|c|}
\hline Unit cell & \multicolumn{2}{|c|}{ Least squares (space group: $R 3 m$ ) } & \multirow[b]{2}{*}{$7.0638(9)$} \\
\hline$a(\AA)$ & $15.731(3)$ & $c$ & \\
\hline$\theta$ limit & $0.4-35.0^{\circ}$ & Scan type & $\omega / 2 \theta$ \\
\hline Scan time(s) & \multicolumn{2}{|l|}{$\leq 60 \mathrm{~s}$} & \\
\hline Orientation standards & $3 / 300$ reflections & Intensity standards & 3 per 4 hrs \\
\hline Data collected & $5278, \pm h, \pm k,-1$ to $l$ & $R_{\text {mago }}$ & 0.017 \\
\hline Unique data & \multicolumn{2}{|l|}{957} & \\
\hline Data $>4 a_{7}$ & 869 & Variables & 104 \\
\hline Goodness-of-fit: & \multicolumn{2}{|l|}{0.699} & \\
\hline$R$ & 0.014 & $R_{\mathrm{w}}$ & 0.017 \\
\hline \multicolumn{4}{|c|}{ Largest peaks on difference map $\left(e / \AA^{3}\right)$} \\
\hline$(+)$ & 0.293 & $(-)$ & 0.316 \\
\hline
\end{tabular}

Note: Numbers in parentheses denote one ESD of least units cited. 
sion refinement. A second dataset was collected on a ground sphere that was originally split from the crystal described here, and a conventional hemisphere $(+h, \pm k$, $\pm l$ ) was collected. The resulting structure was found to be essentially identical to that documented here, and thus is not reported.

The structure was routinely refined using a tourmaline starting model, $I>3 \sigma_{I}$ data, and neutral-atom scattering factors with terms for anomalous dispersion. Absorption was corrected using $360^{\circ} \Psi$-scan data for four reflections and, after refinement of the atomic arrangement, the absorption-surface method as implemented in program DifABs (Walker \& Stuart 1983) was used. A weighting scheme with weights proportional to $\sigma^{-2}$, with a term to downweigh intense reflections, was used throughout the refinement. $\mathrm{B}, \mathrm{O} 1-\mathrm{O} 8$, and $\mathrm{H} 3$ were constrained to fully occupy their respective sites, and the $Y$ and $Z$ sites were modeled with Al scattering factors, with unconstrained multiplicity. Occupancy of the $T$ site was modeled with $\mathrm{Si}$ and B scattering factors, with the assumption that $(\mathrm{Si}+\mathrm{B})=1$. The $\mathrm{H}$ atom associated with $\mathrm{O} 3$ (H3) was easily located in the difference map, and subsequently refined. No $\mathrm{H}$ atom was found near O1.

Table 2 contains the atom coordinates and equivalent-isotropic displacement parameters, and Table 3 lists the anisotropic-displacement parameters for the atoms. Table 4 shows selected bond-lengths. Structure factors may be obtained from the Depository of Umpublished Data, CISTI, National Research Council, Ottawa, Ontario K1A 0S2, Canada.

TABLE 2. POSITIONAL PARAMETERS, ISOTROPIC $B$ VALUES, AND BOND-VALENCE SUMS FOR ATOMS IN OLENITE

\begin{tabular}{|c|c|c|c|c|c|c|}
\hline Aton & $x$ & $y$ & $z$ & $B\left(\AA^{2}\right)$ & Occupancy & BVS \\
\hline$X$ & 0 & 0 & $1 / 4$ & $1.25(2)$ & $\mathrm{Na}_{0.93 !(1)} \square_{0.069}$ & 0.83 \\
\hline$T$ & $0.19113(2)$ & $0.18921(2)$ & $0.03576(7)$ & $0.530(5)$ & $\mathrm{Si}_{0.855(2)} \mathrm{B}_{0.145}$ & 3.80 \\
\hline$B$ & $0.10896(7)$ & $2 x$ & $0.4856(3)$ & $0.64(3)$ & $\mathrm{B}_{1.00}$ & 3.01 \\
\hline$Y$ & $0.12153(5)$ & $1 / 2 x$ & $-0.3248(1)$ & $0.65(1)$ & $\mathrm{Al}_{0.826(1)} \square_{0.174}$ & 2.34 \\
\hline$Z$ & $0.29662(2)$ & $0.26057(3)$ & $-0.35807(7)$ & $0.579(5)$ & $\mathrm{Al}_{0.96 \%(1)} \square_{0.031}$ & 3.01 \\
\hline $\mathrm{O} 1$ & 0 & 0 & $-0.1937(4)$ & $1.08(3)$ & $\mathrm{O}_{1.00}$ & 1.36 \\
\hline $\mathrm{O} 2$ & $0.05978(5)$ & $2 x$ & $0.5249(2)$ & $1.10(2)$ & $\mathrm{o}_{1.00}$ & 1.90 \\
\hline $\mathrm{O} 3$ & $0.2591(1)$ & $1 / 2 x$ & $-0.4590(2)$ & $1.00(3)$ & $\mathrm{O}_{1.0 \mathrm{~A}}$ & 1.09 \\
\hline $\mathrm{O} 4$ & $0.09386(6)$ & $2 x$ & $0.1105(2)$ & $1.12(3)$ & $\mathrm{O}_{1.09}$ & 1.98 \\
\hline 05 & $0.1858(1)$ & $1 / 2 x$ & $0.1314(2)$ & $1.13(3)$ & $\mathrm{O}_{1.00}$ & 1.92 \\
\hline 06 & $0.19334(6)$ & $0.18281(6)$ & $-0.1913(2)$ & $0.74(1)$ & $\mathrm{O}_{1.00}$ & 1.92 \\
\hline 07 & $0.28671(6)$ & $0.28591(6)$ & $0.1098(1)$ & $0.76(1)$ & $O_{1.00}$ & 1.98 \\
\hline 08 & $0.20940(6)$ & $0.26979(6)$ & $0.4705(1)$ & $0.72(1)$ & $\mathrm{O}_{1.00}$ & 2.06 \\
\hline $\mathrm{H}$ & $0.248(2)$ & $1 / 2 x$ & $0.423(5)$ & $1.35(74)^{*}$ & $\mathrm{H}_{1.00}$ & \\
\hline
\end{tabular}

Starred atoms were refined isotropically. Anisotropically refined atoms are given in the form of the isotropic equivalent-displacement parameter defined as: $(4 / 3)^{*}\left[a^{2} * \beta_{11}+b^{2 *} \beta_{22}+c^{2 *} \beta_{33}+a b(\cos \gamma)^{*} \beta_{12}+a c(\cos \beta)^{*} \beta_{13}+b c(\cos \alpha)^{*} \beta_{23}\right]$ BVS: bond-valence sum.

\section{Chemical analysis}

The crystal chosen for the structure refinement was analyzed for constituents with atomic number $\geq 9$ (Table 5) with a wavelength-dispersion ARL SEMQ electron microprobe (EMP) at the University of Maine (accelerating voltage $15 \mathrm{kV}$, beam current $10 \mathrm{nA}$, and spot size $3 \mu \mathrm{m}$ ). Natural silicates and oxides were used as standards, and data were processed with a $\phi(\rho z)$ scheme, in which the effect of $0.59 \mathrm{wt} \% \mathrm{Li}_{2} \mathrm{O}, 15.1 \mathrm{wt} \%$ $\mathrm{B}_{2} \mathrm{O}_{3}$ and $3.25 \mathrm{wt} \% \mathrm{H}_{2} \mathrm{O}$ were included. The concentration of $\mathrm{Li}$ and $\mathrm{B}$ was established by secondary ion mass spectrometry (SIMS) with a Cameca ims 4f ion micro-

TABLE 3. ANISOTROPIC-DISPLACEMENT PARAMETERS FOR THE ATOMS IN OLENITE

\begin{tabular}{lllllll}
\hline Atom & $\beta_{11}$ & $\beta_{22}$ & $\beta_{33}$ & $\beta_{12}$ & $\beta_{13}$ & $\beta_{23}$ \\
\hline
\end{tabular}

Si $\quad 0.00069(1) \quad 0.00064(1) \quad 0.00254(5) \quad 0.00047(1)-0.00001(5)-0.00035(5)$ $\begin{array}{lllllll}{ }^{\gamma} \mathrm{Al} & 0.00077(3) & 0.00069(2) & 0.0044(1) & \beta_{11} & -0.0007(1) & \beta_{13} / 2\end{array}$

${ }^{7} \mathrm{Al} \quad 0.00076(1) \quad 0.00088(1) \quad 0.00271(5) \quad 0.00086(1)-0.00033(5) \quad 0.00023(5)$

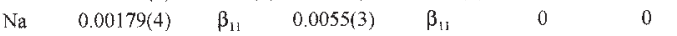

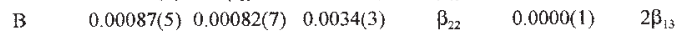
$\begin{array}{lllllll}01 & 0.00153(6) & \beta_{11} & 0.0049(4) & \beta_{14} & 0 & 0\end{array}$ $\begin{array}{llllll}02 & 0.00168(5) & 0.00069(5) & 0.0065(2) & \beta_{22} & 0.0001 .(1)\end{array} \quad 2 \beta_{13}$ $\begin{array}{lllllll}03 & 0.00229(7) & 0.00124(4) & 0.0032(2) & \beta_{11} & -0.0007(2) & \beta_{13} / 2\end{array}$ $\begin{array}{lllllll}04 & 0.00139(4) & 0.00189(7) & 0.0052(2) & \beta_{22} & -0.0005(1) & 2 \beta_{13}\end{array}$ $\begin{array}{lllllll}\text { O5 } & 0.00202(7) & 0.00143(4) & 0.0050(3) & \beta_{11} & 0.0002(2) & \beta_{1 / 2} / 2\end{array}$ $06 \quad 0.00092(3) \quad 0.00095(3) \quad 0.0037(1) \quad 0.00076(4) \quad 0.0000(1)-0.0002(1)$ o7 $\quad 0.00103(3) \quad 0.00101(3) \quad 0.0034(1) \quad 0.00084(4) \quad 0.0005(1) \quad-0.0002(1)$ $\begin{array}{llllllll}08 & 0.00076(3) & 0.00108(3) & 0.0040(1) & 0.00091(4) & 0.0004(1) & 0.0011(1)\end{array}$

The form of the anisotropic-displacement parameter is: $\exp \left[-\left(\beta_{11} * h^{2}+\beta_{22} * k^{2}+\beta_{33}^{* h^{2}}+\beta_{12}^{*} h k+\beta_{13}^{*} h l+\beta_{23}^{*} d \delta\right)\right]$

TABLE 4. SELECTED INTERATOMIC DISTANCES $(\AA)$ IN AUSTRIAN OLENITE

\begin{tabular}{|c|c|c|c|c|c|}
\hline \multirow[t]{3}{*}{$X-$} & $\mathrm{O} 2(\times 3)$ & $2.533(2)$ & \multirow[t]{3}{*}{$T-$} & $\mathrm{O} 4$ & $1.608(2)$ \\
\hline & $04(\times 3)$ & $2.740(1)$ & & 05 & $1.622(1)$ \\
\hline & $05(\times 3)$ & $2.666(2)$ & & 06 & $1.607(2)$ \\
\hline \multicolumn{2}{|c|}{ Mean } & 2.647 & & 07 & $1.600(1)$ \\
\hline & & & \multicolumn{2}{|c|}{ Mean } & 1.609 \\
\hline \multirow[t]{4}{*}{$Y-$} & O1 & $1.8965(18)$ & \multirow[t]{2}{*}{$B-$} & $O_{2}$ & $1.3683(7)$ \\
\hline & O $2(\times 2)$ & $1.955(1)$ & & $08(\times 2)$ & $1.373(2)$ \\
\hline & 03 & $2.100(2)$ & \multirow{2}{*}{\multicolumn{2}{|c|}{ Mean }} & 1.371 \\
\hline & $06(\times 2)$ & $1.918(1)$ & & & \\
\hline \multicolumn{2}{|c|}{ Mean } & 1.957 & & & \\
\hline \multirow[t]{6}{*}{$Z-$} & 03 & $1.971(1)$ & & & \\
\hline & 06 & $1.880(2)$ & & & \\
\hline & 07 & $1.878(2)$ & & & \\
\hline & $07^{\circ}$ & $1.920(2)$ & & & \\
\hline & 08 & $1.888(2)$ & & & \\
\hline & $08^{\circ}$ & $1.877(2)$ & & & \\
\hline \multicolumn{2}{|c|}{ Mean } & 1.902 & & & \\
\hline
\end{tabular}


probe operated at the University of New Mexico (UNM) by a UNM - Sandia National Laboratories consortium. Analyses were made using primary ${ }^{16} \mathrm{O}^{-}$ions accelerated through a nominal potential of $12.5 \mathrm{kV}$. A primary beam current of 10-20 nA was focused on the sample over a spot diameter of $15-20 \mu \mathrm{m}$. Sputtered secondary ions were energy-filtered using a sample offset voltage of $50 \mathrm{~V}$ and an energy window of $\pm 25 \mathrm{~V}$. The analyses

TABLE 5. CHEMICAL COMPOSITION AND UNIT FORMULA OF OLENITE FROM KORALPE, AUSTRIA

\begin{tabular}{|c|c|c|c|c|}
\hline & Ertl ef $a .^{1}$ & This paper ${ }^{2}$ & This paper ${ }^{2}$ & This paper ${ }^{3}$ \\
\hline $\mathrm{SiO}_{2} \mathrm{wt}^{\circ} \%$ & $31.96(19)$ & $31.43(58)$ & $31.43(58)$ & 31.455 \\
\hline $\mathrm{TiO}_{2}$ & $0.02(2)$ & $0.02(3)$ & $0.02(3)$ & --- \\
\hline $\mathrm{B}_{2} \mathrm{O}_{3}$ & $16.06(31)$ & $16.20(66)^{4}$ & $15.25^{5}$ & 15.250 \\
\hline $\mathrm{Al}_{2} \mathrm{O}_{3}$ & $46.71(10)$ & $46.53(32)$ & $46.53(32)$ & 46.318 \\
\hline $\mathrm{Cr}_{2} \mathrm{O}_{3}$ & -- & $0,00(1)$ & $0.00(1)$ & --- \\
\hline $\mathrm{FeO}$ & $0.05(2)$ & $0.05(4)$ & $0.05(4)$ & -- \\
\hline $\mathrm{MnO}$ & $0.01(2)$ & $0.02(2)$ & $0.02(2)$ & -- \\
\hline $\mathrm{ZnO}$ & $-\ldots$ & $0.08(6)$ & $0.08(6)$ & -- \\
\hline $\mathrm{MgO}$ & $0.01(1)$ & $0.00(1)$ & $0,00(1)$ & -- \\
\hline $\mathrm{CaO}$ & $1.47(3)$ & $1.74(3)$ & $1.74(3)$ & 1.778 \\
\hline $\mathrm{Li}_{2} \mathrm{O}$ & $0.54(-)$ & $0.56(1)^{4}$ & $0.56(1)^{+}$ & 0.575 \\
\hline $\mathrm{Na}_{2} \mathrm{O}$ & $1.46(3)$ & $1.33(17)$ & $1.33(17)$ & 1.337 \\
\hline $\mathrm{K}_{2} \mathrm{O}$ & $0.02(1)$ & $0.00(0)$ & $0.00(0)$ & --- \\
\hline $\mathrm{F}$ & $0.11(2)$ & $0.12(7)$ & $0.12(7)$ & 0.123 \\
\hline $\mathrm{Cl}$ & $\ldots$ & $0.00(0)$ & $0.00(0)$ & --- \\
\hline $\mathrm{H}_{2} \mathrm{O}$ & $3.25(-)$ & $3.25(-)^{6}$ & $3.25(-)^{6}$ & 3.216 \\
\hline $\mathrm{O}=\mathrm{F}$ & -0.05 & -0.05 & -0.05 & -0.052 \\
\hline Sum & 101.58 & 101.15 & 100.20 & 100.00 \\
\hline$n$ & 31 & 31 & 31 & $30.795^{7}$ \\
\hline Si apfu & 4.875 & 4.813 & 4.873 & 4.854 \\
\hline$\left[{ }^{[4]} \mathrm{B}\right.$ & 1.229 & 1.283 & 1.081 & 1.062 \\
\hline${ }^{[4]} \mathrm{Al}$ & --- & -- & 0.046 & 0.084 \\
\hline Sum $T$ site & 6.104 & 6.096 & 6.000 & 6.000 \\
\hline${ }^{[3]} \mathrm{B}$ & 3.000 & 3.000 & 3.000 & 3.000 \\
\hline $\mathrm{Al}$ & 8.398 & 8.400 & 8.457 & 8.340 \\
\hline $\mathrm{Fe}$ & 0.006 & 0.006 & 0.006 & --- \\
\hline $\mathbf{L i}$ & 0.331 & 0.343 & 0.347 & 0.357 \\
\hline Sum $Y, Z$ sites & 8.735 & 8.749 & 8.810 & 8.697 \\
\hline $\mathrm{Ca}$ & 0.240 & 0.286 & 0.289 & 0.294 \\
\hline $\mathrm{Na}$ & 0.432 & 0.394 & 0.399 & 0.400 \\
\hline $\mathbf{K}$ & 0.004 & 0 & 0 & -- \\
\hline Sum $X$ site & 0.676 & 0.680 & 0.688 & 0.694 \\
\hline Sum cations & 18.515 & 18.525 & 18.498 & 18.391 \\
\hline $\mathbf{H}$ & 3.307 & 3.320 & 3.361 & 3.31 \\
\hline $\mathbf{F}$ & 0.053 & 0.058 & 0.059 & 0.06 \\
\hline Sum $\mathrm{OH}+\mathrm{F}$ & 3.360 & 3.378 & 3.420 & 3.37 \\
\hline
\end{tabular}

Note: ${ }^{1}$ Average of 10 EMP analyses (esd in parentheses). Formula is newly calculated. ${ }^{2}$ Average of 20 EMP analyses for major constituents; 10 analyses for $\mathrm{Cr}_{2} \mathrm{O}_{3}, \mathrm{ZnO}, \mathrm{F}, \mathrm{Cl}$ (10 standard deviation in parentheses). ${ }^{3} \mathrm{Wt} . \%$ calculated from optimal site-occupancies and normalized to $100 \%$. ${ }^{4}$ Average of three SIMS analyses (10 standard deviation in parentheses). ${ }^{5}$ From the optimal site-occupancy (next column). ${ }^{6}$ From Ertl et al. (1997). ${ }^{7}$ Value is 0.205 less than 31 because of deficient total positive charge Dashes: not analyzed. A component is not considered significant unless its value exceeds the uncertainty; measured $\mathrm{ZnO}$ content is not considered significant. involved repeated cycles of peak counting on ${ }^{7} \mathrm{Li},{ }^{11} \mathrm{~B}$ and ${ }^{30} \mathrm{Si}$. The analytical procedure included counting on a background position to monitor detection noise. Absolute concentrations of each element were calculated using empirical relations of measured ${ }^{7} \mathrm{Li}^{+} /{ }^{30} \mathrm{Si}^{+}$and ${ }^{11} \mathrm{~B}^{+} /{ }^{30} \mathrm{Si}^{+}$ratios (normalized to known $\mathrm{SiO}_{2}$ content) to element concentrations as derived from daily calibration measurements of tourmaline standards. In the three tourmaline standards, the concentration of $\mathrm{Li}$ has been measured by atomic absorption by John Husler (UNM), and $\mathrm{B}_{2} \mathrm{O}_{3}$ by a variety of nuclear methods (Dyar et al. 1998 , in prep.). We assumed that the $\mathrm{H}_{2} \mathrm{O}$ content determined by Karl Fischer titration on a bulk sample (Ertl et al. 1997) is valid for the crystal selected for structure analysis.

Results of an electron-microprobe analysis by H.-J. Bernhardt (Ertl et al. 1997; this paper, Table 5, col. 1) and by MGY (Table 5, col. 2-3) are in very good agreement for all the major constituents with $Z \geq 9$ if allowance is made for $\mathrm{Ca}_{0.04}$ replacing $\mathrm{Na}_{0.04}$. Moreover, the SIMS-derived Li content is in good agreement with the atomic absorption measurement reported by Ertl et al. (1997). The EMP value reported for $\mathrm{B}_{2} \mathrm{O}_{3}$ by Ertl et al. (1997) is consistent with the SIMS value obtained here. Nonetheless, the high analytical totals could result from overestimation of $\mathrm{B}_{2} \mathrm{O}_{3}$ by both EMPA and SIMS.

Boron coordination can affect the amount of boron established by EMPA if only peak height is measured (McGee \& Anovitz 1996). The latter authors found that the $\mathrm{B}_{2} \mathrm{O}_{3}$ content in danburite $\left({ }^{[4]} \mathrm{B}\right.$ only) was overestimated by $20 \%$ using uvite $\left({ }^{[3]} \mathrm{B}\right.$ only) as a standard. Extrapolating this result to olenite, for which the refinement gives ${ }^{[4]} \mathrm{B} / \mathrm{B}$ ratio equal to 0.26 , we estimate the EMPA $\mathrm{B}_{2} \mathrm{O}_{3}$ content of $16.06 \mathrm{wt} \%$ obtained with dravite ( ${ }^{[3]} \mathrm{B}$ only) as a standard is $5 \%$ too high, i.e., an EMPA $\mathrm{B}_{2} \mathrm{O}_{3}$ content corrected for differences in coordination between dravite and olenite would be $15.26 \mathrm{wt} \%$, in good agreement with that calculated from the refinement (Table 5).

In the case of SIMS, it is possible that the matrix for olenite is sufficiently different from the matrixes of the tourmaline standards as to affect ion yields. A difference in matrix was cited to explain excessively high B content obtained for boralsilite despite its crystallographic relationship to the grandidierite used as a standard (Grew et al. 1998). In the present case, there is even greater similarity in crystal structure between standards (dravite - schorl - elbaite solid solutions) and unknown (olenite). However, the standards contain far more Fe and $\mathrm{Mn}$; these two ions constitute 4.7 to $12 \%$ of the total cations (Dyar et al. 1998, sample nos. 1-3) versus $0.03 \%$ in the olenite. Ottolini \& Hawthorne (1999) reported that $\mathrm{Fe}$ and $\mathrm{Mn}$ have a substantial matrix effect on the B-ion yield relative to Si-ion yield, i.e., the B/Si count ratio, in schorl-elbaite solid solutions. Their data show that $\mathrm{B} / \mathrm{Si}$ count ratio decreases by about $10 \%$ as $(\mathrm{Fe}+\mathrm{Mn})$ cations increase from 0 to $5 \%$ of the total cations. Given the difference in $\mathrm{Fe}+\mathrm{Mn}$ contents 
between the three standards and olenite, the SIMS-derived B content of the olenite could be at least $10 \%$ too high. This excess is more than sufficient to explain the $6 \%$ discrepancy between the SIMS-derived B content and that calculated from the refinement, especially given the large uncertainty associated with the SIMS value. The discrepancy in the two B values is also sufficient to explain the high analytical total (Table 5). Ottolini \& Hawthorne (1999) also reported an even greater matrix effect for $\mathrm{Fe}+\mathrm{Mn}$ content on ion yield of Li relative to $\mathrm{Si}$. However, given the low concentration of Li relative to that of $\mathrm{B}, \sim 0.5$ versus $\sim 15 \mathrm{wt} \%$, the matrix effects for $\mathrm{Li}$ will not materially affect the resulting formula.

\section{Optimization of site occupancies}

Using methods of quadratic programming, Wright et al. (2000) offer a method of optimizing the site occupancies of cation sites in minerals with multiply occupied cation sites. Using that method with the structure refinement and chemical data obtained in this study, and $B$ excluded from the octahedral sites, the structural formula of the Austrian olenite is $\left(\mathrm{Na}_{0.400} \mathrm{Ca}_{0.294} \square_{0.306}\right)$ ${ }^{Y}\left(\mathrm{Al}_{2.424} \mathrm{Li}_{0.357} \square_{0.219}\right){ }^{Z}\left(\mathrm{Al}_{5.916} \square_{0.084}\right) \mathrm{B}_{3.00}{ }^{T}\left(\mathrm{Si}_{4.854}\right.$ $\left.\left.\mathrm{B}_{1.062} \mathrm{Al}_{0.084}\right) \mathrm{O}_{27}\left[\mathrm{~F}_{0.06}\left(\mathrm{OH}_{3.31}\right) \mathrm{O}_{0.63}\right)\right]$. We will use this formula in later discussions of the structure; the optimized formula essentially minimizes the differences between the formula obtained from the results of the chemical analysis and that obtained by SREF.

\section{Physical properties}

Because of the unique nature of the olenite described herein, we list here several of the physical properties as given by previous authors. Ertl \& Brandstätter (1998) determined optical properties of the phase, and gave $\omega$ $1.668(2), \varepsilon 1.644(2)$, and observed weak yellow fluorescence in ultraviolet light $(253.7 \mathrm{~nm})$. Ertl et al. (1997) listed $\mathrm{D}_{\text {calc }}$ as 3.057, and $\mathrm{D}_{\text {meas }}$ as 3.02(4).

\section{Discussion of the Atomic Arrangement}

The Austrian olenite is the first natural tourmaline in which ${ }^{[4]} \mathrm{B}$ was identified and found to be present in substantial amounts; this example clearly shows that the substitution of Si by ${ }^{[4]} \mathrm{B}$ does occur in tourmaline-group minerals. This sample allows characterization of the structural effects of this tetrahedral substitution.

\section{The T site}

Hawthorne (1996) examined the incorporation of light elements in tourmaline, including the substitution of ${ }^{[4]} \mathrm{B}$ for ${ }^{[4]} \mathrm{Si}$. He noted that the disparate sizes of ${ }^{[4]} \mathrm{B}$ and ${ }^{[4]} \mathrm{Si}$ ( 0.11 and $0.26 \AA$, respectively) should be reflected in the $\langle T-\mathrm{O}\rangle$ distance, and demonstrated that the $\langle T-\mathrm{O}\rangle$ distance in extant structures supports the presence of ${ }^{[4]} \mathrm{Al}$ but not ${ }^{[4]} \mathrm{B}$. The variation in $\langle T-\mathrm{O}\rangle$ distances in Hawthorne's data could be explained by a linear combination of $\mathrm{Si}-\mathrm{O}$ bonds $(<1.62 \mathrm{~A}>)$ and $\mathrm{Al}-$ O bonds $(<1.75 \AA\rangle)$, without addition of $\mathrm{B}(\langle\mathrm{B}-\mathrm{O}\rangle=$ $1.47 \AA)$. In the Austrian olenite, the $\langle T-\mathrm{O}\rangle$ distance $(1.609 \AA)$, is too short to be due to any combination of just ${ }^{[4]} \mathrm{Si}$ and ${ }^{[4]} \mathrm{Al}$. Using the optimized formula, with tetrahedrally occupants $\left(\mathrm{Si}_{4.854} \mathrm{~B}_{1.062} \mathrm{Al}_{0.084}\right)$ and the average $T-\mathrm{O}$ bond lengths above, a $\langle T-\mathrm{O}\rangle$ bond length of $1.595 \AA$ is predicted, using the hard-sphere model.

\section{The $X$ and $Y$ sites}

Optimization of the site occupancies of the cation sites confirmed the putative ordering of $\mathrm{Li}$ at the $Y$ site. Originally, Ertl et al. (1997) had assumed that all vacancies were located at the $Y$ site, but optimization suggested that vacant sites occur in both the $Y$ and $Z$ octahedra, as shown above. No occupants other than Al, $\mathrm{Li}$ and a trace of $\mathrm{Fe}$ were found by chemical analysis.

\section{O1, O3 sites}

Hydroxyl and $\mathrm{F}$ occur at the $\mathrm{O} 1$ and $\mathrm{O} 3$ sites. In the Austrian olenite, $\mathrm{H} 3$ (the site associated with $\mathrm{O} 3$ ) was easily located as the highest peak in the near-final difference-Fourier map, and the position and isotropic-displacement parameter refined without problem; thus $\mathrm{O} 3$ was assigned as $\mathrm{OH}$. No difference peak was found near $\mathrm{O} 1$, and that site was assigned the remaining anions, with final occupancy $\left[\mathrm{F}_{0.06}(\mathrm{OH})_{0.31} \mathrm{O}_{0.63}\right]$. However, as discussed below, it can be argued that ${ }^{Y}(\mathrm{Li}+\square)=$ ${ }^{o 1}(\mathrm{OH}+\mathrm{F})$; thus $0.21(\mathrm{OH})$ assigned to $\mathrm{O} 3$ probably resides at the $\mathrm{O} 1$ site, and the $\mathrm{O} 3$ site is not completely occupied by $\mathrm{OH}$.

\section{Short-range order}

Hawthorne (1996) evaluated the structural mechanisms for light-element variations in tourmaline. $\mathrm{He}$ showed, using bond-valence arguments, that a $Y$ octahedron occupied by $\mathrm{Li}$ "cannot be involved in local coordination to $\mathrm{O}^{2-}$ at $\mathrm{O} 1$ in the tourmaline structure", as the monovalent $Y$ occupant would be unable to provide sufficient bond-valence to the $\mathrm{O} 1$ oxygen; in a tourmaline with $(\mathrm{Li}, \mathrm{Al}, \square)$ occupying $Y$, the $\mathrm{O} 1$ site can only be occupied by $\mathrm{O}^{2-}$ if $\mathrm{O} 1$ is locally associated with $3 \mathrm{Al}$ at the neighboring $Y$ sites. In other arguments based on bond-valence considerations, Hawthorne (1996) showed that trivalent substituents at tetrahedral sites must be locally associated with $\mathrm{Al}$ at the adjacent $Y$ and $Z$ sites, a requirement easily met in the Austrian olenite. He also showed that there is an advantage for incorporation of a trivalent tetrahedral substituent if the neighboring $X$ site is occupied by $\mathrm{Ca}$.

Substitution of $\mathrm{B}$ at a $T$ site reduces the bond valence to each coordinating oxygen atom by $0.25 v u$ (valence units). The loss in bond valence to the non-bridging atoms of oxygen $(\mathrm{O} 6, \mathrm{O} 7)$ is compensated by insertion of 
trivalent cations at the adjacent $Y$ and $Z$ sites (Hawthorne 1996). The bridging oxygen atoms (O4, O5), however, can only gain a bond-valence contribution from adjacent $T$ and $X$ cations, although $\mathrm{O} 5$ may receive minor bond-valence from the hydrogen bond involving $\mathrm{H} 3$ (calculated as $0.04 v u$ here). In the Austrian olenite, the $X$ site contains $\left(\mathrm{Na}_{0.40} \mathrm{Ca}_{0.29} \square_{0.31}\right)$. The $X$-site occupancy allows conjecture on the degree of order of $\mathrm{B}$ atoms in individual six-membered rings of tetrahedra; two different schemes of order are possible.

The amount of ${ }^{[4]} \mathrm{B}$ in the optimized formula $\left({ }^{[4]} \mathrm{B}=\right.$ 1.06 apfu) allows, on average, approximately one ${ }^{[4]} \mathrm{B}$ per six-membered ring. Calcium and $\mathrm{Na}$ as $X$-site cations adjacent to ${ }^{[4]} \mathrm{B}$ would provide 0.12 and $0.08 v u$, respectively, to an adjacent $\mathrm{O} 4$, as opposed to $0.00 v u$ for an adjacent $X$-site vacancy. For the $\mathrm{O} 5$ bridging oxygen atom in the ring of tetrahedra, $\mathrm{Ca}$ and $\mathrm{Na}$ would provide 0.15 and $0.10 v u$, respectively, and an adjacent $X$-site vacancy would obviously provide $0.00 \mathrm{vu}$. Clearly, in all cases, the adjacent $\mathrm{Ca}$ atom is preferred as a mechanism to satisfy the bond-valence requirements of the bridging atoms of oxygen, although $\mathrm{Na}$ also provides significant bond-valence to the bridging oxygen atoms as well. The suggestion of Hawthorne (1996) that a trivalent substituent in the tetrahedral site is favored by a $\mathrm{Ca}$ atom in the adjacent $X$ site is supported by the bond-valence values given above, and $\mathrm{Na}$ as a "second-choice" $X$-site neighbor also contributes bond valence to the bridging oxygen atoms. An adjacent vacancy, however, would make local satisfaction of the bond-valence requirements of bridging oxygen atoms difficult to achieve. Thus, bond-valence arguments can be used to suggest that each ${ }^{[4]} \mathrm{B}$ substituent must be accompanied locally by ${ }^{X} \mathrm{Ca}$ or ${ }^{X} \mathrm{Na}$. It is of interest that $\mathrm{Ca}$ in $X$ is exactly equal to ${ }^{1 / 3}{ }^{[4]} \mathrm{B}(0.29$ apfu $\mathrm{Ca}, 0.87$ apfu ${ }^{\left[{ }^{4]} \mathrm{B}\right)}$ as determined from SREF, but the disparity between the B content determined by SREF and chemical analysis does not allow simple assignment of three ${ }^{[4]} \mathrm{B}$ to each silicate ring adjacent to $\mathrm{Ca}$. However, as many rings of tetrahedra must have more than one ${ }^{[4]} \mathrm{B}$ atoms if adjacent $X$-site vacancies are prohibited, charge-balance arguments can be used to suggest that those rings adjacent to $\mathrm{Ca}$ will contain ${ }^{[4]} \mathrm{B}_{3}{ }^{[4]} \mathrm{Si}_{3}$. In each of the rings so occupied ( $29 \%$ of the total rings), Ca would occupy the adjacent $X$-site; we can also conjecture that the $\mathrm{O} 1$ site adjacent to that $X$ site is occupied by $\mathrm{O}^{2-}$, not $\mathrm{OH}$, because of the $\mathrm{Ca}$ occupant. With those rings so occupied, many silicate rings with a Na neighbor at the $X$ site (not $\square$ ) must also contain ${ }^{[4]} \mathrm{B}$, although not necessarily with three substituents per ring. Table 6 lists possible configurations of site-occupants on the basis of these arguments [listed as scheme (1)].

A second scheme of order for ${ }^{[4]} \mathrm{B}$ can be offered. The value of ${ }^{[4]} \mathrm{B}$ (1.06 apfu) corresponds to an average of one ${ }^{[4]} \mathrm{B}$ per silicate ring, and it is tempting to assume that the ordering occurs by limiting substitution to one ${ }^{[4]} \mathrm{B}$ per six-membered ring of tetrahedra. Because the level of substitution in $T$ sites by trivalent substituents in the Austrian olenite is unprecedented, it is not clear what level of distortion actually occurs from extensive incorporation of trivalent ions. Hawthorne (1996) argued that the substitution of trivalent substituents in the ring of tetrahedra is favored in those rings with $\mathrm{Ca}$ at the adjacent $X$ site, the divalent $X$-site occupant being able to satisfy the bond-valence requirements of the locally associated bridging oxygen atoms, O4 and $\mathrm{O} 5$. Assuming one ${ }^{[4]} \mathrm{B}$ atom per ring, with the $X$-site occupancies in the Austrian olenite, only $29 \%$ of the rings would have $\mathrm{Ca}$ at the adjacent $X$-site; an additional $40 \%$ of the rings would have $\mathrm{Na}$ atom at the adjacent $X$-site. However, $31 \%$ of the rings would have an associated vacant $X$-site, providing no additional bond-valence for the bridging oxygen atoms. As noted above, $\mathrm{O} 4$ and $\mathrm{O} 5$ adjacent to a vacant $X$-site would lose 0.12 and $0.15 v u$, respectively, relative to those bridging oxygen atoms in a substituted ring with $\mathrm{Ca}$ atom at the adjacent $X$-site. It is not clear that structural adjustments can compensate for that loss of bond valence. Table 6 lists possible configurations of site-occupants based on one B atom per ring [listed as scheme (2)].

Inference about short-range configurations at other sites also can be made. For each $\mathrm{O}^{2-}$ at the $\mathrm{O} 1$ site, the adjacent three $Y$ sites can be occupied by $\mathrm{Al}$ only, but not Li or $\square$, the only other possible occupants. Associated with that local configuration, a six-Si-membered

TABLE 6. POSSIBLE SHORT-RANGE-ORDER CONFIGURATIONS IN AUSTRIAN OLENITE

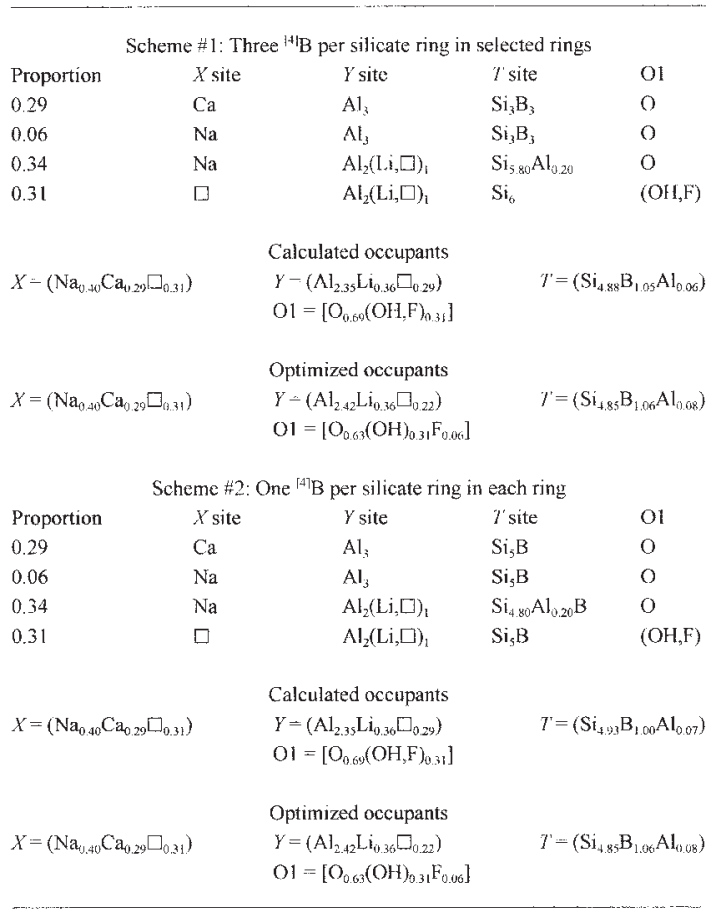


ring can exist, with $\mathrm{Na}$ at the adjacent $X$-site. A third type of short-range pattern can also be inferred. With an Al-Al-Li or Al-Al- $\square$ configuration in a triplet of $Y$ octahedral sites, only $\mathrm{OH}$ or $\mathrm{F}$ can occur at the adjacent $\mathrm{O} 1$ site. In the Austrian olenite, ${ }^{Y}(\mathrm{Li}+\square)$ equals 0.58 , and the minimum $(\mathrm{F}+\mathrm{OH})$ equals 0.37 ; thus it is suggested that $0.21 \mathrm{OH}$ molecules assigned to $\mathrm{O} 3$ actually resides in $\mathrm{O} 1$.

In Table 6, we list the suggested $X, Y, T$, and $\mathrm{O} 1$ site occupancies based on the short-range-order arguments given above, and compare the observed occupants of those sites and the occupants obtained by optimization.

\section{SUMMARY}

Numerous attempts had been made to find a tourmaline with ${ }^{[4]} \mathrm{B}$. Although spectroscopic studies have suggested that small amounts of boron can occur at the $T$ in the tourmaline structure (Tagg et al. 1999), structure studies have not (until now) unequivocally shown B to exist in greater than 3 apfu in tourmaline. With the discovery of the olenite from a metapegmatite from Stoffhütte, Austria, tourmaline with substantial ${ }^{\left[{ }^{4}\right]} \mathrm{B}$ is found to exist, on the order of one ${ }^{[4]} \mathrm{B}$ per six tetrahedral sites. The material is not particularly remarkable in its atomic arrangement. The discovery of olenite that contains nearly one ${ }^{[4]} \mathrm{B}$ apfu in a pegmatite that had been metamorphosed at $2 \mathrm{GPa}$ pressure after intrusion suggests that a high-pressure environment may be necessary for the crystallization of tourmaline with significant ${ }^{[4]} \mathrm{B}$.

\section{ACKNOWLEDGEMENTS}

We thank Peter Schmitzer, Graz, Austria, for providing the samples of the olenite. The structure portion of this work was supported by NSF grants EAR9627222 and 9804768 (JMH). The electron microprobe and SIMS analyses were supported by NSF grant OPP9813569 to the University of Maine. Associate Editor George W. Robinson and reviewers Frank C. Hawthorne and M. Novák provided invaluable comments on the work. Editor-in-Chief Robert F. Martin provided his usual insightful comments, and his efforts on behalf of the entire discipline are sincerely appreciated.

\section{REFERENCES}

Bernhardt, H.-J., BrandstÄtter, F., ERtL, A., KöRner, W., Mikenda, W. \& PeRTLIK, F. (1999): Untersuchungen an einem borhaltigen Muskovit-2 $\mathrm{M}_{1}$ von der Koralpe, Steiermark. Annalen des Naturhistorischen Museums in Wien 100A, 1-11.

Bloodaxe, E.S., Hughes, J.M., Dyar, M.D., Grew, E.S. \& GuidotTI, C.V. (1999): Linking structure and chemistry in the schorl-dravite series. Am. Mineral. 84, 922-928.
Burns, P.C., MacDonald, D.J. \& Hawthorne, F.C. (1994): The crystal chemistry of manganese-bearing elbaite. Can. Mineral. 32, 31-41.

Dyar, M.D., Taylor, M.E., Lutz, T.M., Francis, C.A., Guidotti, C.V. \& Wise, M. (1998): Inclusive chemical characterization of tourmaline: Mössbauer study of Fe valence and site occupancy. Am. Mineral. 83, 848-864.

ERTL, A. \& BRANDSTÄTTER, F. (1998): Olenit mit Borüberschuß aus einem Metapegmatit östlich der Stoffhütte, Koralpe, Steiermark. Österreich. Mitt. Abteilung für Mineralogie am Landesmuseum Joanneum 62/63, 3-21.

Pertlik, F., \& Bernhardt, H.-J. (1997): Investigations on olenite with excess boron from the Koralpe, Styria, Austria. Österreich. Akad. Wissenschaften, Mathematisch-naturwissenschaftliche Klasse, Anzeiger Abt. 1, 134, 3-10.

FRENZ, B.A. (1997): SDP for Windows Reference Manual. B.A. Frenz \& Associates, Inc., College Station, Texas.

Grew, E.S., McGee, J.J., Yates, M.G., Peacor, D.R., Rouse, R.C., Huijsmans, J.P.P., SHeARER, C.K., WiEdEnBECK, M., Thost, D.E. \& Su, Shu-Chun (1998): Boralsilite $\left(\mathrm{Al}_{16} \mathrm{~B}_{6} \mathrm{Si}_{2} \mathrm{O}_{37}\right)$ : a new mineral related to sillimanite from pegmatites in granulite-facies rocks. Am. Mineral. 83, 638651 .

HAWTHORNE, F.C. (1996): Structural mechanisms for light-element variations in tourmaline. Can. Mineral. 34, 123-132.

Lichem, C., Hoinkes, G. \& Gregurek, D. (1997): Polymetamorphism of the Austroalpine Koralm basement: new evidence for a Permian event. Terra Nova 9, Abstr. Suppl. 1, 489 .

McGee, J.J. \& Anovitz, L.M. (1996): Electron probe microanalysis of geological materials for boron. In Boron Mineralogy, Petrology and Geochemistry (E.S. Grew \& L.M. Anovitz, eds.). Rev. Mineral. 33, 771-788.

Miller, C. \& ThÖNI, M. (1997): Eo-Alpine eclogitisation of Permian MORB-type gabbros in the Koralpe (Eastern Alps, Austria): new geochronological, geochemical and petrological data. Chem. Geol. 137, 283-310.

OtTolini, L. \& HAwTHORNE, F. C. (1999): An investigation of SIMS matrix effects on $\mathrm{H}, \mathrm{Li}$ and B ionization in tourmaline. Eur. J. Mineral. 11, 679-690.

Postl, W. \& Moser, B. (1988): Mineralogische Notizen aus der Steiermark. Mitt. der Abteilung für Mineralogie am Landesmuseum Joanneum 56, 5-47.

Schreyer, W., Wodara, U., Marler, B., van Aken, P.A., SEIFERT, F. \& Robert, J.-L. (2000): Synthetic tourmaline (olenite) with excess boron replacing silicon in the tetrahedral site. I. Synthesis conditions, chemical and spectroscopic evidence. Eur. J. Mineral. 12, in press. 
STÜwe, K. \& Powell, R. (1995): PT paths from modal proportions: application to the Koralm Complex, Eastern Alps. Contrib. Mineral. Petrol. 119, 93-93.

TAGG, S.L., Cho, H., Dyar, M.D. \& GREW, E.S. (1999): Tetrahedral boron in naturally occurring tourmaline. Am. Mineral. 84, 1451-1455.

THÖNI, M. (1999): A review of geochronological data from the Eastern Alps. Schweiz. Mineral. Petrogr. Mitt. 79, 209-230.

\& MilleR, C. (1996): Garnet Sm-Nd data from the Saualpe and the Koralpe (Eastern Alps, Austria): chronological and P-T constraints on the thermal and tectonic history. J. Metamorph. Geol. 14, 453-466.

WALKer, N. \& StUART, D. (1983) An empirical method for correcting diffractometer data for absorption effects. Acta Crystallogr. A39, 158-166.
Wodara, U. \& Schreyer, W. (1997): Turmaline mit Borüberschuß im System $\mathrm{Na}_{2} \mathrm{O}-\mathrm{Al}_{2} \mathrm{O}_{3}-\mathrm{B}_{2} \mathrm{O}_{3}-\mathrm{SiO}_{2}-\mathrm{H}_{2} \mathrm{O}$ (NABSH). Ber. Deutsch. Mineral. Ges. 1, 394 (abstr.).

\& (1998): Tetrahedral boron in tourmalines of the system $\mathrm{Na}_{2} \mathrm{O}-\mathrm{Al}_{2} \mathrm{O}_{3}-\mathrm{B}_{2} \mathrm{O}_{3}-\mathrm{SiO}_{2}-\mathrm{H}_{2} \mathrm{O}$. Terra Nova, 10, Abstr. Suppl. 1, 68-69.

Wright, S.E., Foley, J.A. \& Hughes, J.M. (2000): Optimization of site occupancies in minerals using quadratic programming. Am. Mineral. 85, 524-531.

Received January 10, 2000, revised manuscript accepted June 7, 2000. 